approval for EPO nowadays," says an industry insider who requests anonymity.

John Greenwood, head of regulatory affairs at GeneMedix, says the CPMP has not insisted on additional studies for marketing approval of his company's generic EPO because of the "PRCA situation." But he does recognize that the Eprex case could have a greater impact on the regulatory requirements imposed on biogenerics companies after the product reaches the market. Indeed, Phase 3 trials are carried out in too few patients to reveal adverse events, such as PRCA, that typically occurs in only one out of 10,000 patients. After Eprex, "post marketing surveillance will be a prerequisite for follow-on biologics," says Greenwood. CPMP guidelines have provisions that would enable the committee to request postmarketing surveillance studies for biogenerics if deemed necessary.

As the number of biogenerics approved increases, the EMEA will have to ensure compliance for postmarketing surveillance. Nevertheless, biogeneric observers do not see noncompliance as a threat. "If [biogeneric] companies don't comply, they risk blocking the future of biogenerics by setting a precedent," says Kox.

Sabine Louët, London

\title{
UK government caught in GM dilemma
}

Two high-profile committees commissioned by UK Prime Minister Tony Blair to examine the prospects for genetically modified (GM) food have produced downbeat conclusions on the technology's commercial and safety implications. Blair must now decide whether to comply with European law and allow commercial exploitation of GM crops in the face of widespread popular dissent, or contradict his well-known pro-GM stance by deferring the planting of GM crops.

On July 21, a panel led by the UK government's chief scientific adviser, David King, published its review of findings on the safety of GM technology. The panel concluded that each new variety of GM crop should be scrutinized for possible risks and benefits to human health and the environment, even though the current generation of GM crops poses little risk. "The conclusion is not that we simply go ahead," cautions King.

The King report follows an even less optimistic study from the department of environment's Strategy Unit, released July 11. That report dismisses GM crops as offering negligible economic benefits to the UK, at least until GM crops more adapted to the UK environment are available that show significant benefits to UK farmers or consumers (Nat. Biotechnol. 21, 839-842, 2003).

Both reports leave Blair holding a political time bomb. If Blair opposes the release of new GM products in the UK, he would be contravening the European directive on deliberate GM organism (GMO) release (2001/18). Under European law, no individual EU country has the right to forbid release of GM organisms in their own territories after they have been approved by other member states.

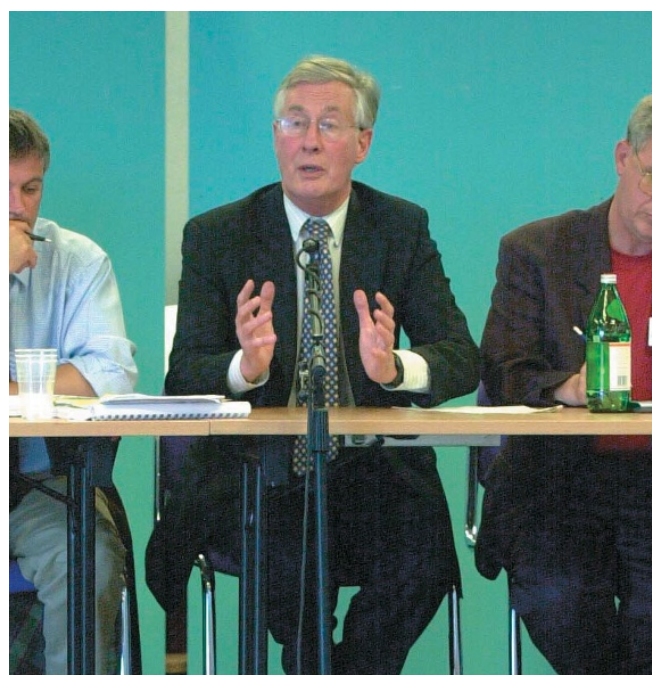

Former Environment Minister Michael Meacher, on the trail of his anti-GM campaign.

And with the first GM products likely to get European approval by early 2004, Blair has to decide whether GM crop planting should go ahead in the United Kingdom before the year's end.

So what should the UK government do? Vivian Moses, of the industry-funded science advisory panel Cropgen (London, UK), recommends a 'go-for-it' strategy. "We are in grave danger of losing a major part of the science base in this country, and we [shouldn't] deny GM technology to UK farmers," he says.

An EU survey of academia and the industry, published in March, reiterates this warning. More than $60 \%$ of survey respondents in the private sector have cancelled R\&D projects on GM crops, and the number of GM field trial applications in the EU has fallen by 76\% between 1998 and 2002 (Nat. Biotechnol.
21, 468-469, 2003). "We have to maintain $\mathrm{R} \& \mathrm{D}$ so as to keep the door open for the future," says Bernard Marantelli, a spokesperson for the industry-funded Agriculture Biotechnology Council (London, UK). "The industry won't keep its R\&D going on the offchance that in seven years the government might say yes."

But independent experts in the politics of GM agriculture believe the government faces an almost intractable problem. Joyce Tait of Edinburgh University contends that the apparent impartiality of the two recent reports represent an attempt by the government to preserve its options, in advance of the decision it has to make at the end of this year. "I don't think ministers have yet made their minds up how to come to a conclusion," says Tait.

Disagreements concerning biotechnology are common at the heart of government. In June, Blair sacked his environment minister, Michael Meacher, who was widely regarded by the biotechnology industry as lukewarm about GM technology. Since then, Meacher has been openly criticizing the government's GM policy, claiming that GM crops cannot coexist with so-called 'organic' agriculture, a big consumer market in the UK. The King report reinforces these concerns stressing that certain GMOs-especially oilseed rape (canola)—would inevitably contaminate nearby non-GM plantations.

The UK public is also fiercely opposed to GM crops. A UK Food Standards Agency (London, UK) report published in July found that most UK consumers remain suspicious of GM crops. And the UK's official public debate on the issue, 'GM nation' (Nat. Biotech. 21, 593-595, 2003), has come under heavy criticism for its lack of effectiveness, even before the final consultation report, scheduled for September, has been published. "Given the amount of negative public and press comment there has been, I think it would take a considerable degree of political courage to make a pro-GM decision," says Tait.

Yet the UK has always been one of the EU's most pro-GM states and would put itself in a very awkward position if it did a volte face and voted against approvals now. A keenly awaited scientific study commissioned by the department of environment on the farmscale evaluation of three herbicide-tolerant GM crops, expected mid-October, could provide information on individual crops that the government might need to decide whether to approve GM crops in the UK.

Pete Mitchell, London 